\title{
AZ ALKOHOLOS HALANDÓSÁG SZEREPE A VÁRHATÓ ÉLETTARTAM ISKOLAI VÉGZETTSÉG SZERINTI EGYENLŐTLENSÉGEIBEN
}

\section{THE ROLE OF ALCOHOL-RELATED MORTALITY IN LIFE EXPECTANCY INEQUALITIES BY EDUCATIONAL LEVEL}

\author{
Bálint Lajos ${ }^{1}$, Németh László2 \\ 'tudományos főmunkatárs, KSH Népességtudományi Kutatóintézet \\ balint@demografia.hu \\ ²tudományos segédmunkatárs, KSH Népességtudományi Kutatóintézet \\ nemeth@demografia.hu
}

\begin{abstract}
ÖSSZEFOGLALÁS
A tanulmány az alkohol okozta halandóság szerepét tárgyalja az iskolázottság szerinti élettartam-különbségekben a rendszerváltozás időszakában és két évtizeddel később Magyarországon. A vizsgált időszakokat összehasonlítva megállapíthatjuk, hogy számottevően csökkent a közvetlenül az alkoholnak tulajdonítható élettartam-veszteség valamennyi iskolázottsági csoportban. Mindeközben a legalább középiskolai érettségivel rendelkezők és az annál alacsonyabb iskolai végzettségűek közötti várható élettartambeli különbség tovább növekedett ebben a periódusban, tovább mélyítve ezzel a kilencvenes évek elején már jelentősnek mondható megosztottságot.
\end{abstract}

\section{ABSTRACT}

In our study, we aim to disentangle the effect of alcohol-related mortality on life expectancy and lifespan equality for different educational groups at the time of the regime change and two decades later. Our results reveal that in this period, mortality due to alcohol consumption has significantly decreased on the whole for the Hungarian population and separately for each education group as well. Although life expectancy has generally increased for all groups, the gap between the least and most educated groups has also increased, leading to higher inequality in life expectancy in the country.

Kulcsszavak: halandóság Magyarországon, alkoholos halandóság, iskolázottság szerinti várható élettartam, halandóságitábla-módszerek, többszörös kilépési táblák, várható élettartam dekomponálása, élettartam veszteség

Keywords: mortality in Hungary, alcohol-related mortality, life expectancy by educational level, life table methods, multiple decrement life tables, decomposition of life expectancy, life lost 


\section{BEVEZETÉS}

A tanulmányban elöször a túlzott alkoholfogyasztás halandóságban játszott szerepét mutatjuk be, ezt követően az iskolázottsági csoportok differenciált érintettségének szakirodalmi tapasztalatait ismertetjük, az adatok és módszerek ismertetését követően az alkoholos halandóság iskolázottsági különbségeit mutatjuk be különböző eszközök segítségével.

Az alkoholfogyasztás, különösen a nagy mennyiségủ alkoholfogyasztás számos megbetegedés kockázati tényezője. Az akut alkoholos befolyásoltság növeli a balesetek és sérülések előfordulását, míg a krónikus súlyos alkoholfogyasztás lényegében minden szervet károsít. Kockázati tényezője a májcirrózisnak, a daganatok különböző típusainak, a kardiovaszkuláris megbetegedéseknek, hozzájárul a hormonrendszer zavaraihoz, az anyagcsere-betegségekhez, a vázizomzat nagyfokú károsodásához (Lapis, 2002). A mértéktelen alkoholfogyasztás az egészségkárosodás és az idő előtti halálozás mellett számos más, káros társadalmi következményhez vezethet (alkohollal kapcsolatos büncselekmények, családi konfliktusok).

A cirrózis okozta halandóság a túlzott alkoholfogyasztás általánosan elfogadott indikátora. A magyar idősoradatok azt mutatják, hogy a halandóság a hetvenes években kezdett drámaian növekedni, a nyolcvanas években az arányszámok megduplázódtak (Chenet et al., 1998). A nagy mennyiségü alkoholfogyasztásnak meghatározó szerepe volt a kilencvenes évek elején a kelet-európai régióban tetőződő epidemiológiai válságban (Cockerham, 1997). A kilencvenes évek közepén az alkoholos halandóság Európában addig ismeretlen méreteket öltött, és az ezredforduló időszakában is a nemzetközi mezőny élén állt (Bosetti et al., 2007).

A romló cirrózisos halálozási trendeknek köszönhetően az alkohol élettartamra gyakorolt negatív hatása már a nyolcvanas években jelentősnek bizonyult (Chenet et al., 1998). France Meslé (2004) számításai szerint az emésztőrendszeri megbetegedések (amelyek jelentős részét az alkoholos eredetủ májbetegségek teszik ki Magyarországon) okozta élettartam-veszteség 1965 és 1993 között a férfiaknál nagyobb volt (-1,33 év), mint keringési rendszer okozta halálozásoké (-1,25 év). A kilencvenes évek közepén a középkorú (35-45 éves) férfiak körében a májcirrózis a keringési rendszer megbetegedései, valamint a külső okok miatt bekövetkező halandóság mellett az egyik legfontosabb összetevöje volt a korai halálozásoknak.

Egy kortárs európai összehasonlító tanulmány szerint a 35-79 éves népesség körében az alkoholos halandóság mindkét nem esetében Magyarországon volt a legmagasabb (Mackenbach et al., 2015). 


\section{ALKOHOLPROBLÉMA MAGYARORSZÁGON}

Az alkoholkérdés Magyarországon hivatalosan az ötvenes és a hatvanas évek fordulóján vált társadalmi problémává. A kommunista rezsim a jövedelmek dinamikus növelésével igyekezett a társadalmi megbékélést elősegíteni. A fogyasztásra költhető pénzjövedelmek emelkedésével az alkoholfogyasztás is ugrásszerűen növekedett. A fogyasztás térnyerését elősegítette a drámai mértékben növekvő ipari foglalkoztatottak integrációs és adaptációs problémáinak megoldatlansága (Kovács, 1991), valamint az alacsony iskolázottságú társadalmi csoportok megbirkózási képességeinek hiánya (Józan, 2003).

A belkereskedelem és a vendéglátás is érdekelt volt a szeszesital-fogyasztás növekedésében, mivel az élelmiszerek többnyire kötött ára miatt elsősorban a szeszesitalok értékesítéséből származott nyeresége. Hazánkban kínálatkorlátozó intézkedésekre csak a nyolcvanas években került sor. Ezek azonban sokkal kevésbé voltak olyan radikálisak, mint a mintaadó Szovjetunióban, és a rövid távú költségvetési érdekek nálunk is a kezdeményezés elhalásához vezettek (Andorka, 1994).

Az Andorka Rudolf (1994) által hivatkozott adatok szerint 1956 és 1981 között az alkoholfogyasztás háromszorosára nőtt Magyarországon, és az égetett szeszesitalok előretörésével jelentősen átalakult a fogyasztás összetétele is.

Az alkoholfogyasztás mennyiségének időbeli változása rendszerint tükröződik a halálozási ráta változásában. Ennek ellenére Magyarországon a cirrózis okozta halandóság változását nem magyarázta az alkoholfogyasztás időbeli alakulása (Ramstedt, 2007). A kapcsolat hiányát több tényező is okozhatja. Egyrészt felvethető a fogyasztási adatok pontatlansága (alulbecsültsége), másrészt a makroadatok nem részletezik a fogyasztás társadalmon belüli variabilitását. Továbbá komoly érvek szólnak amellett is, hogy a magas alkohol miatti halandóság hátterében az alkohol toxicitásának, a rossz minőségü, házilag előállított szeszesitalok fogyasztásának fontos szerepe lehetett (Szücs et al., 2005; Elekes, 2014).

\section{ISKOLÁZOTTSÁG ÉS ALKOHOL}

Mint számos más egészséggel kapcsolatos magatartást, az alkoholfogyasztás mintázatát is erősen befolyásolja az iskolázottsággal, a foglalkozási helyzettel, a jövedelemmel leírható szocioökonómiai státus. A nemzetközi tapasztalatok azt mutatják, hogy az alkohollal kapcsolatos társadalmi és egészségi problémák gyakoribbak, a halandóság pedig szignifikánsan magasabb az alacsony szocioökonómiai státusú csoportokban (Mackenbach et al., 2015). Egy kortárs vizsgálat eredményei azt mutatják, hogy az iskolai végzettség szerinti abszolút és relatív halandósági különbségek is nagyobbak Kelet-Európában, mint Európa nyugati országaiban (Mackenbach et al., 2015). 
Az alkoholfogyasztás és alkoholos halandóság társadalmi különbségei a hatvanas évek óta ismertek Magyarországon. Andorka és munkatársai a hatvanas évek közepén, hétezer budapesti intézetben kezelt alkoholbeteg adatát dolgozták fel, de nem találtak különbséget az egyes társadalmi és iskolázottsági csoportok között (Andorka et al., 1968). Későbbi elemzések azonban már a társadalmi hierarchiában betöltött pozíció szerint szerveződő kockázatokra, a hátrányosabb társadalmi helyzetű rétegek gyakoribb alkoholfüggőségére mutatnak rá (Andorka, 1990).

Elekes Zsuzsanna és Liptay Gabriella (1987) elemzése azt mutatta meg, hogy a nagyivók aránya számottevően magasabb volt a szakmunkások és a kvalifikálatlan fizikai munkát végzők között. Ezzel szemben a mérsékelt fogyasztók jellemzően magasabb iskolai végzettséggel rendelkeztek, közöttük gyakoribb volt a vezető, értelmiségi foglalkozású.

Miközben az alkoholfogyasztás és a szocioökonómiai státus kapcsolata jól dokumentált a hazai szakirodalomban, addig az alkohollal kapcsolatos halandóság társadalmi jellemzőiről kevesebb ismeretünk van. A fellelhető elemzések a fogyasztási szokásokkal konzisztens halandóságról, az alacsonyabb státusú csoportok sérülékenységéről számolnak be. A nyolcvanas évekből származó vizsgálatok azt mutatják, hogy az önkárosító magatartásformák közül az alkoholizmussal összefüggő májzsugoros halandóság mindkét nem esetében a szellemi foglalkozásúaknál volt legalacsonyabb, őket a munkások, majd a szövetkezeti parasztság követte (Andorka et al., 1986). Az alkoholos májzsugorodás és a társadalmi osztályok közötti kapcsolat részletesebb rétegséma mellett is a napjainkban jól ismert inverz kapcsolatot mutatta (Andorka, 1990). Egy hazai vonatkozású területi elemzés a depriváció szintje és az alkohol okozta májbetegségek okozta halálozások között talált szoros kapcsolatot a férfiaknál (Nagy et al., 2013).

\section{ADATOK ÉS MÓDSZER}

A tanulmányban szereplő halálozási adatok a Központi Statisztikai Hivatal népességregiszteréből (Demográfiai táblázó), a népesség adatok pedig az 1990-es és a 2011. évi népszámlálás adatállományából származtak. A halálozások esetében a három év halálozási eseteit, a cenzus mellett az azt megelőző és követő évek adatát is figyelembe vettük, ezzel igyekeztünk a koréves halálozási adatok bizonytalanságát csökkenteni. A kockázati népesség valamennyi év esetében megegyezett, feltételeztük, hogy a népesség iskolázottság szerinti megoszlása a vizsgált időszakban korévenként identikus volt.

A halandósági táblákat befejezett iskolai végzettség szerint a 25-90 éves korévekre határoztuk meg. Az iskolarendszer sajátosságai miatt négy iskolai végzettség elemzésére (kevesebb mint nyolc osztály, legfeljebb szakmunkás végzettségüek /8-11 év/, érettségizettek /12-13 év/ és diplomások /15 $\leq /$ ) nyílt lehetőségünk. 
A szakmunkásképzés csak a hatvanas évek elején indult el Magyarországon, ezért esetükben a felnőttkori életszakasz egészére halandósági tábla nem számítható. Mivel a szakmunkások halandósága leginkább az alacsonyabb iskolai végzettségủekkel mutat hasonlóságot, ezért őket a legfeljebb nyolc osztályt végzettekkel vontuk össze. A második időszakban (2009-2011) a halálozási rekordok 7,7\%-ánál az iskolai végzettség ismeretlen volt. A hiányzó adatokat a legközelebbi szomszéd módszerével pótoltuk.

Tanulmányunkban nyolc fontosabb betegségcsoport szerepel. Az alkohollal kapcsolatos halálokok között szerepelnek azok, amelyek közvetlenül és döntően az alkoholnak tulajdoníthatóak (alkohol okozta mentális és viselkedés zavarok, BNO-9: 291, 303, 305; BNO-10: F10, alkoholos polineuropátia 375.5; G62.1, alkoholos kardiomiopátia 425.5; I42.6, alkoholos gasztritisz (gyomorhurut) 535.3; K29.2, alkoholos májbetegségek 571.0-571.3; K70, alkoholos idült hasnyálmirigy-gyulladás 577.1; K86.0-K86.1, balesetszerü mérgezés alkohol által E860; X45, szándékos önmérgezés alkohol által 9509; X65, nem meghatározott szándékú mérgezés alkohol által 9809; Y15). Hasonlóan diverz betegségkört ölel fel a dohányzás okozta halálesetek csoportja (ajak, szájüreg, garat 140-150; C00-C14, gége 161; C32, légcső, hörgő, tüdő rosszindulatú daganata 162; C33-C34, idült alsó légúti betegségek 490-494, J40-J44). Ezeken kívül a keringési rendszer megbetegedéseit (szív- és agyérbetegségek), a nem dohányzásos eredetü rosszindulatú daganatok okozta halálozásokat, a nem alkoholos eredetủ emésztőrendszeri betegségeket, a külső okokat, továbbá az egyéb, máshova nem sorolt haláleseteket vettük figyelembe.

Az elemzés a standardizált halandósági arányszámok mellett különböző halandósági táblán alapuló mutatók segítségével történt. A halandósági tábla típusú elemzés előnye, hogy az élettartamban kifejezett abszolút különbségek, a relatív kockázatokkal és a standardizált mutatókkal ellentétben pontosabb képet adnak az egyes eltérések jelentőségére vonatkozóan, és bárki számára könnyen értelmezhetök.

Az élettartam-különbségeket a Evgeny Andreev és szerzőtársai által kidolgozott algoritmus (Andreev et al., 1982) alapján bontottuk fel. Az eljárás lehetővé teszi két eltérő iskolázottságú csoport élettartam-különbségeinek korévenkénti meghatározását és ezeknek a különbségeknek halálokok szerint történő felbontását is. A koréves eredményeket a könnyebb értelmezhetőség érdekében ötéves korcsoportokba vontuk össze. Az összehasonlítás alapjául a felsőfokú végzettséggel rendelkező iskolázottsági csoportot választottuk, amely a legkedvezőbb túlélési valószínüséggel, így a legmagasabb várható élettartammal rendelkezett mindkét megfigyelt időszakban, nemtöl függetlenül.

A halálozáskori átlagos életkort és a halálozások valószínüségét halálokok szerint többszörös kilépési táblák segítségével mutatjuk be, feltételezve, hogy a teljes halandóság additív módon szeparálható (Preston et al., 2001). 
A halálozásokban tapasztalható egyenlőtlenségekről további információt szolgáltat az élettartam-egyenlötlenség mutató (life disparity), amely az átlagos várható élettartamot méri a halál bekövetkezésének pillanatában, azaz megmutatja, hogy mekkora várható élettartamtól esik el a vizsgált népesség a halálozás következtében.

Az alkoholos halálozás sokkal gyakoribb a férfiak körében, mint a nőknél, ezért terjedelmi okok miatt elemzésünkben föképp a férfiak eredményeire fókuszálunk.

\section{EREDMÉNYEK}

\section{Az alkohollal kapcsolatos halandóság alakulása Magyarországon}

A közvetlenül az alkoholnak köszönhető halálokok közül az alkohol okozta májbetegségek dominanciája meghatározó Magyarországon (1. ábra). A férfiaknál jelentősebbnek mondható az alkoholos mentális betegségek, illetve az alkoholos kardiomiopátia is. Az időbeli trendek mindkét nem esetében hasonlóak, a kilencvenes évek közepéig meredek emelkedés mutatkozott az alkoholos halálozás szintjében, amit ugyancsak jelentős csökkenés követett. Valamennyi okot figyelembe véve a halálozási arányszámok napjainkban is magasabbak, mint a nyolcvanas évek elején.
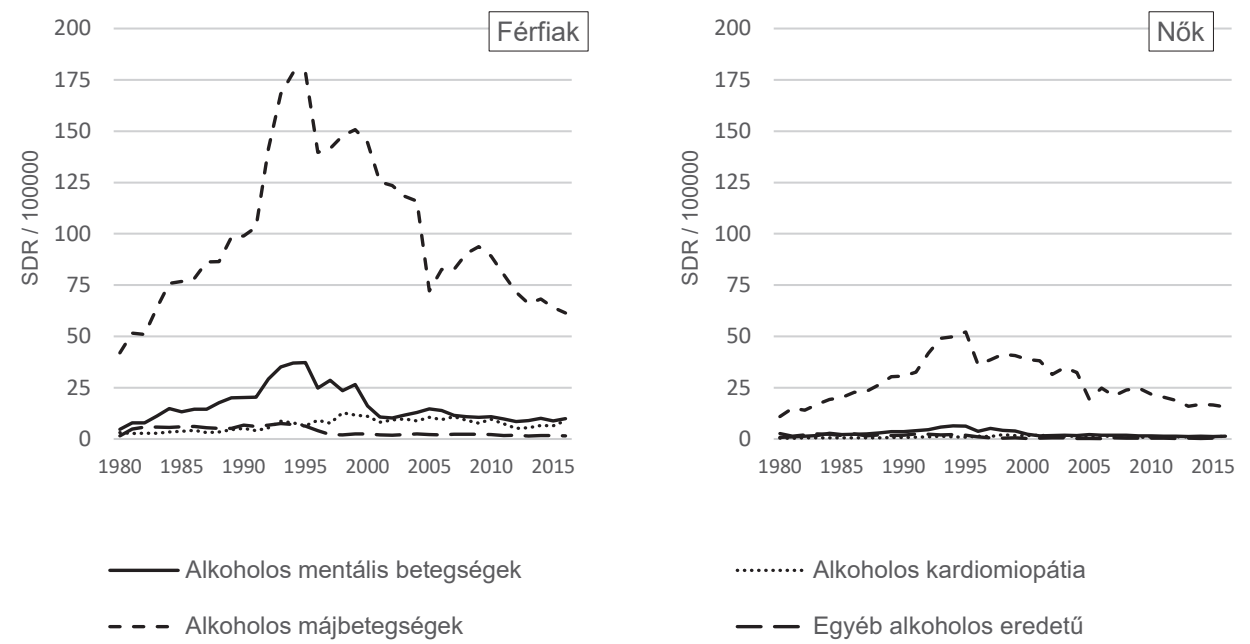

1. ábra. Az alkohollal kapcsolatos halálokok standardizált arányszámai a 25 éves és idősebb népesség körében, 1980-2016

(KSH Demográfiai táblázó adatai alapján, saját szerkesztés) 
A vizsgált időszakban a különböző iskolázottságú csoportok tagjainak 25 éves életkorban várható élettartama a legalacsonyabb iskolázottságú nők kivételével emelkedett, a javulás mértéke azonban eltérő volt (1. táblázat). A legjelentősebb előrelépés az érettségizetteknél következett be, őket a diplomások, majd a legfeljebb szakmunkás, szakiskolai végzettségúek követték. A javulás differenciáltságának köszönhetően a magasabb iskolázottságú csoportok közötti élettartam-különbségek csökkentek, míg a szélső iskolázottságú csoportok között jelentősen nőttek. A diplomás férfiak 25 éves korban várható élettartama 2011-ben 54,25 év volt, a befejezetlen általános iskolai végzettségűeké ennél közel tizenöt évvel kevesebb, mindösszesen 38,46 év, míg korábban a különbség „csak” 11,8 év volt. A nőknél szintén markáns divergencia figyelhetö meg, a legmagasabb és a legalacsonyabb iskolázottságúak közötti különbség 6,1 évröl 10,5 évre emelkedett, és mérsékelten ugyan, de nőtt a legfeljebb szakmunkás végzettségüek leszakadása is. Ugyanakkor fontos hangsúlyozni, hogy az alapfokú képzettséggel sem rendelkezők egyre kisebb arányát alkotják a társadalomnak.

1. táblázat. A 25 éves és idősebb korban várható élettartam befejezett iskolai végzettség szerint, az 1989-1991 és 2010-2012 években

\begin{tabular}{|l|c|c|c|c|}
\hline \multirow{2}{*}{\multicolumn{1}{|c|}{ Iskolai végzettség }} & \multicolumn{2}{c|}{ Férfiak } & \multicolumn{2}{c|}{ Nők } \\
\cline { 2 - 5 } & $\mathbf{1 9 8 9 - 9 1}$ & $\mathbf{2 0 1 0 - 1 2}$ & $\mathbf{1 9 8 9 - 9 1}$ & $\mathbf{2 0 1 0 - 1 2}$ \\
\hline Kevesebb mint 8 osztály & 38,46 & 39,65 & 48,10 & 47,32 \\
Legfeljebb szakmunkás vagy szakiskola & 40,16 & 44,51 & 50,24 & 53,27 \\
Érettségizett & 44,48 & 50,67 & 50,09 & 56,24 \\
Diplomás & 49,23 & 54,25 & 54,23 & 57,77 \\
Együtt & 42,14 & 47,00 & 50,31 & 54,25 \\
\hline
\end{tabular}

(A KSH Demográfiai táblázó és népszámlálási adatai alapján, saját számítás)

\section{ÉLETTARTAM-VESZTESÉG}

A várható élettartam emelkedésével az élettartam-egyenlőtlenség mutató rendszerint csökken, köszönhetően annak, hogy a halálozás bekövetkezésének idöpontja egyre közelebbi, azonos életkorokra sürüsödik össze. Ha 1990-ben minden férfit egyszer, halálának pillanatában megmentettünk volna, átlagosan 21,8 életévvel lett volna magasabb a várható élettartam, míg ez a mutató 2011-ben 17,74 év (táblázatban nem szerepel). A nőkre sokkal kisebb mértékủ egyenlőtlenség jellemző, a halálokok életkor szerinti eloszlásában a mutató értéke 1990 környékén 
14,52 év, két évtizeddel később 11,37 évre esett vissza. Ez azt is jelenti, hogy a két nem nagyon hasonló módon, 20 százalékkal kisebb élettartam-egyenlőtlenséget ért el 2011-re 1990-hez képest.

A vizsgált időszakokban a legnagyobb egyenlőtlenség a kevesebb mint nyolc osztályt végzett férfiak körében volt megfigyelhető (2. táblázat). A legfeljebb

2. táblázat. Átlagos élettartam-veszteség nemek és halálokok szerint

\begin{tabular}{|c|c|c|c|c|c|c|c|c|}
\hline \multirow{2}{*}{ Halálokok } & \multicolumn{4}{|c|}{ 1989-1991 } & \multicolumn{4}{|c|}{ 2010-2012 } \\
\hline & $<8$ & $8-11$ & $12-13$ & $15 \leq$ & $<8$ & 8-11 & $12-13$ & $15 \leq$ \\
\hline \multicolumn{9}{|l|}{ Férfiak } \\
\hline Daganatok & 2,35 & 2,79 & 3,01 & 2,82 & 2,50 & 2,70 & 2,67 & 2,46 \\
\hline Agyérbetegségek & 2,69 & 2,29 & 1,70 & 1,31 & 2,03 & 1,45 & 0,90 & 0,63 \\
\hline Szívbetegségek & 7,75 & 6,95 & 6,25 & 4,98 & 7,30 & 5,63 & 4,06 & 3,11 \\
\hline $\begin{array}{l}\text { Egyéb } \\
\text { emésztőrendszeri }\end{array}$ & 0,83 & 0,90 & 0,82 & 0,66 & 0,96 & 0,61 & 0,41 & 0,41 \\
\hline Alkoholos & 1,72 & 1,83 & 1,14 & 0,73 & 0,90 & 1,40 & 0,84 & 0,65 \\
\hline Dohányzásos & 3,40 & 2,70 & 2,01 & 1,49 & 3,84 & 2,86 & 1,70 & 1,15 \\
\hline Külső okok & 4,05 & 4,42 & 3,46 & 2,90 & 2,04 & 3,84 & 2,78 & 2,08 \\
\hline Egyéb & 2,58 & 1,34 & 1,04 & 0,80 & 4,72 & 1,63 & 1,12 & 0,89 \\
\hline Összesen & 25,37 & 23,23 & 19,44 & 15,70 & 24,28 & 20,12 & 14,48 & 11,37 \\
\hline \multicolumn{9}{|l|}{ Nők } \\
\hline Daganatok & 2,63 & 3,50 & 4,15 & 3,66 & 2,23 & 2,99 & 3,17 & 3,25 \\
\hline Agyérbetegségek & 2,04 & 1,81 & 1,48 & 1,06 & 1,43 & 1,00 & 0,62 & 0,48 \\
\hline Szívbetegségek & 5,39 & 4,23 & 3,65 & 2,78 & 5,20 & 3,47 & 2,22 & 1,73 \\
\hline $\begin{array}{l}\text { Egyéb } \\
\text { emésztőrendszeri }\end{array}$ & 0,56 & 0,74 & 0,61 & 0,38 & 0,56 & 0,46 & 0,37 & 0,23 \\
\hline Alkoholos & 0,80 & 0,96 & 0,68 & 0,34 & 0,30 & 0,51 & 0,35 & 0,23 \\
\hline Dohányzásos & 1,33 & 0,81 & 0,97 & 0,88 & 3,02 & 1,36 & 1,01 & 0,79 \\
\hline Külső okok & 1,46 & 1,91 & 1,98 & 1,78 & 0,78 & 1,21 & 1,10 & 0,94 \\
\hline Egyéb & 2,37 & 1,12 & 1,00 & 0,75 & 4,22 & 1,55 & 0,93 & 0,74 \\
\hline Összesen & 16,59 & 15,08 & 14,52 & 11,63 & 17,74 & 12,56 & 9,77 & 8,40 \\
\hline
\end{tabular}

(A KSH Demográfiai táblázó és népszámlálási adatai alapján, saját számítás) 
szakmunkás végzettségủ férfiakra számított mutató 1990-ről 2011-re közel 3,11 évvel csökkent, de még mindig kiugróan magasnak számít. A különböző iskolázottsági csoportokat tekintve a legnagyobb egyenlőtlenségcsökkenés az érettségizettek között fordult elö, 4,96 a férfiak, illetve a nők esetében 4,75 évvel kisebb érték a korábbi adathoz mérten. A kevesebb mint nyolc osztályt végzett nők számára az egyenlőtlenség nőtt. Míg 1990-ben átlagosan 16,59 életévet vesztettek a halálozásnak köszönhetően, addig 2011-ben ez a mutató már 17,74 életév volt.

Az egyes halálokok szerinti felbontást megvizsgálva látható, hogy az alkohol hatása az elvesztett élettartamokra 2011-re jelentősen csökkent. Korábban, a diplomával rendelkezőket kivéve, az alkoholfogyasztáshoz köthető halálesetek több mint egy évvel növelték az elvesztett életévek számát a férfiak esetében. 2011-ben azonban csak a legfeljebb szakmunkás bizonyítvánnyal rendelkezők esetében volt kiugróan magas ez az érték. A nőknél a két alacsonyabb végzettségű csoport számára jelentősebb az alkohol hozzájárulása az élettartam-egyenlőtlenséghez, de 2011-re a különböző iskolai végzettségủ csoportok közötti különbségek jelentősen csökkentek. Mindkét nemnél elsősorban a keringési rendszer megbetegedései, a daganatok és a külső okok a meghatározóak. Az alacsonyabb iskolázottságúaknál a dohányzásos eredetủ halálozások és az egyéb okok is jelentősen növelik az élettartam-veszteséget.

\section{Többszörös kilépési táblák eredményei}

A többszörös kilépési táblák lehetővé teszik a konvencionális halandósági táblák komponenseikre (halálokokra) történő felosztását. Az ilyen típusú tábla információt ad a meghaltak halálokok szerinti átlagos halálozási koráról és az egyes halálokok halálozási valószínűségéről. E két komponens súlyozott aritmetikai átlaga a várható élettartam.

Az alkohollal kapcsolatos halálokokban meghaltak átlagos életkora az elemzett halálokok közül a legalacsonyabbak közé tartozik, és messze elmarad az átlagosan várható élettartamtól. Jelentősen alacsonyabb a keringési rendszer és a daganatos betegségekben meghaltak átlagos korától, amelynek áldozatai tipikusan az idősebb életkorúak közül kerülnek ki (2. ábra). Az iskolai végzettség emelkedésével a halálozási életkor rendszerint az alkoholos eredetủ halálozásoknál is emelkedik. Egyúttal a halálozás valószínúsége csökken, ami az alkoholabúzus iskolázottsági csoportok szerinti különbségét jelzi.

Az alkohollal kapcsolatos halálesetekben meghaltak átlagos életkora a férfiaknál közel öt évvel emelkedett minden iskolai végzettségi kategóriában 1990-hez képest. Mivel a vizsgált periódus alatt a kialakult májcirrózis terápiájában jelentős elörelépés még nem történt, így jó okunk van feltételezni, hogy az alkoholfogyasztás mennyiségi és minőségi változása is hozzájárulhatott a javuláshoz. Ezzel párhuzamosan az alkoholos halálozások valószínúsége a három alacso- 

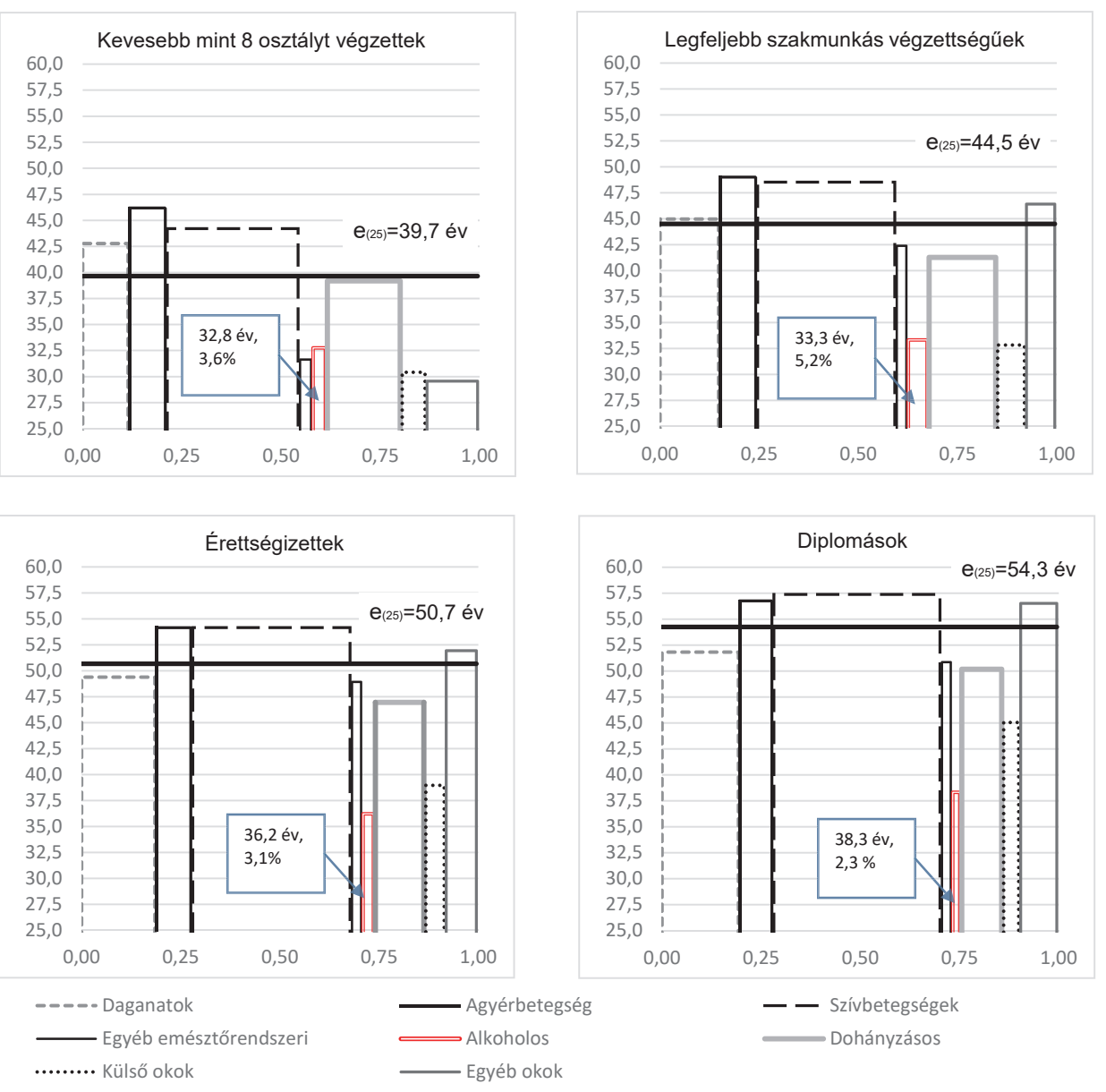

2. ábra. A különböző iskolázottságú férfiak átlagos halálozási kora és az egyes halálokok bekövetkezési valószínűsége, 2010-2012

(A KSH Demográfiai táblázó és népszámlálási adatai alapján, saját szerkesztés)

nyabb iskolai végzettségi kategóriába tartozó férfiaknál csökkent $(2,3,0,7$ és 0,2 százalékponttal). Annak a valószínüsége, hogy egy diplomás férfi az alkoholos eredetủ halálokok valamelyikében hal meg, mindössze $1,7 \%$ volt a kilencvenes évek elején, és ettől alig magasabb (2,3\%) két évtizeddel később. Az eredmények megerősítik a bevezetőben megfogalmazott állítást, miszerint az alkohol okozta halandóság az alacsony végzettségü csoportokat fenyegeti leginkább. A nőknél az alkoholos halandóság szerepe lényegesen visszafogottabb, amit a halálozási valószínüségek jóval alacsonyabb ( $2 \%$ és alatti) értékei is jeleznek. 
A halandósági táblák életkor és halálokok szerinti dekomponálásának tapasztalatai

A létező legjobb gyakorlatot mutató diplomásokhoz képest az alacsonyabb iskolázottsági csoportok élettartam-veszteségéhez az alkoholos halandóság eltérő mértékben járult hozzá (3. ábra). A kilencvenes évek elején az alkoholnak köszönhető veszteség a két legalacsonyabb iskolázottságú csoportban meghaladta az összes élettartam-veszteség tizedét (1,2-1,1 év), míg a diplomások és az érettségizettek közötti abszolút különbség már akkor is jóval szerényebb volt (0,4 év). Két évtizeddel
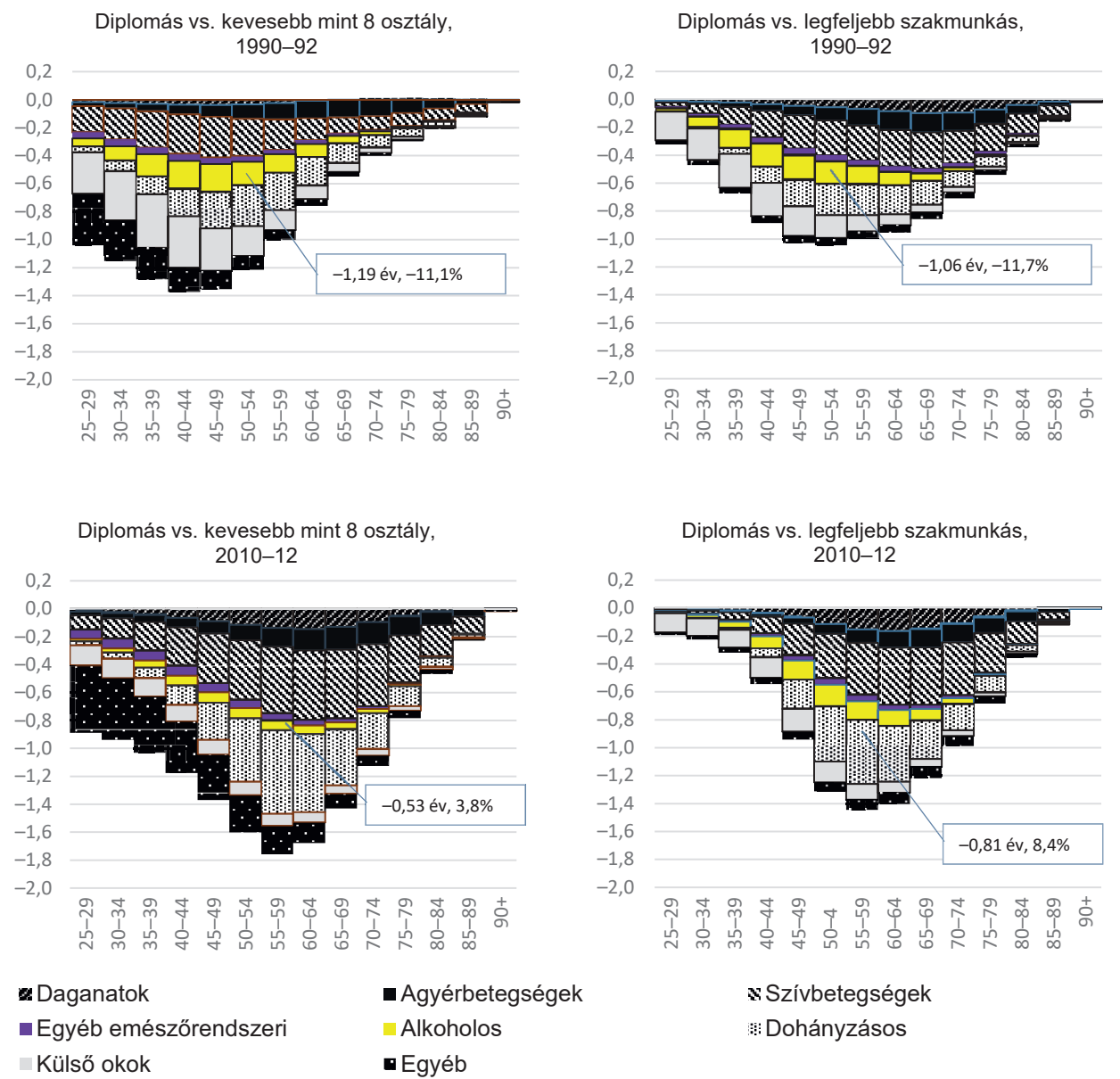

3. ábra. Az egyes halálokok korcsoportonkénti hozzájárulása a diplomások és az alacsonyabb iskolai végzettségű férfiak élettartamának különbségéhez

(A KSH Demográfia táblázó és népszámlálási adatai alapján, saját szerkesztés) 
később az élettartam veszteség $0,5,0,8$ és 0,2 évre csökkent. Az alacsonyabb iskolázottságú csoportok élettartam-különbségének kevesebb mint tizedét magyarázza már csak az alkoholos halandóság. Mivel az alkohol áldozatai fiatalabb életkorban halnak meg, emiatt a szocioökonómiai csoportok közötti különbségek túlnyomó része még a gazdaságilag aktív életkorban, leginkább negyven és hatvan év között figyelhető meg. Az alacsony iskolázottságú népesség tagjainak a diplomásokhoz képest jóval alacsonyabb élettartamát a szív- és érrendszeri megbetegedések, a dohányzásnak köszönhető halálokok okozzák, míg a fiatalabb életszakaszban a halálozások külső okai is jelentős szerepet töltenek be. A férfiakhoz képest a nőknél az alkoholos halandóságnak az élettartam-különbségek létrejöttében játszott szerepe jóval csekélyebb volt. 1990-ben a diplomás és a két legalacsonyabb végzettségü csoport közötti különbség 0,4 év volt, amely 0,1-0,2 évre esett vissza. A nőknél a keringési rendszer megbetegedései okozta halálozások mellett, a dohányzásos eredetủ és egyéb okokat követően lehet a daganatok szerepét említeni.

\section{ÖSSZEFOGLALÁS}

Tanulmányunk a felnőttkori halandóság teljes életkorszegmensét tárgyalta demográfiai módszerek segítségével. Az alkoholos halandóság makrotrendjei, a halandóságitábla-mutatók, valamint az iskolázottsági csoportok közötti különbségek mérséklődése az alkohol szerepének visszaszorulására utalnak. A javulás az iskolázottsági csoportok mindegyikét előnyösen érintette, annak ellenére, hogy a legfeljebb általános iskolát végzett vagy szakmunkás, illetve az érettségizett és diplomával rendelkező népesség élettartam-különbségei ugyanezen idő alatt növekedtek.

Az alkoholos halandóság alapvetően követte a szocioökonómiai státus változását, az iskolázottság emelkedésével csökkent az alkoholos halandóság élettartamra gyakorolt negatív hatása. Az a kivételnek számító eredmény, hogy az általános iskolát be nem fejezők a szakmunkásokénál alacsonyabb alkohol okozta halandósággal rendelkeztek 2011-ben, konzisztens lehet azzal a megfigyeléssel, amely cáfolja, hogy a leginkább marginalizált csoportok többlethalandóságát az alkohol okozná (Kósa et al., 2007).

Bár nemzetközi összehasonlításban az alkohollal kapcsolatos halandóság továbbra is kiemelkedően magas Magyarországon, a direkt okok egyre mérsékeltebb szerepet játszanak az élettartam-különbségek alakításában. Elsősorban a keringési rendszer megbetegedései okozta halálozások, a rosszindulatú daganatok, a man made betegségek közül a dohányzással kapcsolatos halandóság tölt be kulcsfontosságú szerepet.

A tanulmány eredményei világosan mutatják, hogy az iskolázottabbak nem csupán magasabb várható élettartamra számíthatnak, hiszen halálozásuk ugyana- 
zon megbetegedés esetében is később következik be, hanem haláloki struktúrájuk is több ponton eltér a kevésbé képzettekétől. Az egészségpolitikai célkitüzéseknek a mennyiségi különbségek leküzdése mellett számolni kell a kvalitatív jellegü különbségek meglétével is.

Tanulmányunkban az alkoholos halandóságot közvetlenül az alkoholnak tulajdonítható halálokokkal azonosítottuk, azon okokkal, amelyeknek legnagyobb hányadát az alkohol okozza. Ugyanakkor a mértéktelen alkoholfogyasztás a betegségek jóval szélesebb körét is érinti. Például az általunk dohányzásos eredetü halálokok közé sorolt fej-nyak régióhoz tartozó daganatos megbetegedések etiológiájában a töményszesz-fogyasztás is fontos szerepet játszik. Hasonlóan, a túlzott alkoholfogyasztás is a keringési rendszer megbetegedéseit okozó kockázati tényezök között szerepel. Az említett okok figyelmen kívül hagyása miatt bizonyosan alábecsültük az alkoholizmus halandóságban betöltött szerepét, de az általános trendek alapirányzatát ez nem befolyásolja.

\section{IRODALOM}

Andorka R. (1990): Adalékok az alkoholizmus és az öngyilkosság társadalmi rétegek közötti különbségeinek kérdéséhez. Alkohológia, 21, 1, 31-39.

Andorka R. (1994): Alkoholizmus és alkoholpolitika, In: Münnich I. - Moksony F. (szerk.): Devianciák Magyarországon. Budapest: Közélet Kiadó, 266-297.

Andorka R. - Buda B. - Donga K. et al. (1986): Társadalmi beilleszkedési zavarok Magyarországon. I-II. Budapest: Kossuth Kiadó

Andorka R. - Cseh-Szombathy L. - Vukovich Gy. (1968): Alkoholizmus. (KSH Népességtudományi Kutató Intézet Közleményei 24) Budapest: KSH NKI

Andreev, E. M. et al. (1982): Metod komponent v analize prodoljitelnosty zjizni. [The Method of Components in the Analysis of Length of Life]. Vestnik Statistiki, 9, 42-47.

Bosetti, C. - Levi, F. - Lucchini, F. et al. (2007): Worldwide Mortality from Cirrhosis: An Update to 2002. Journal of Hepatology, 46, 827-839. DOI: 10.1016/j.jhep.2007.01.025

Chenet, L. - McKee, M. - Fulop N. et al. (1998): Changing Life Expectancy in Central Europe: Is There a Single Reason? Journal of Public Health Medicine, 18, 3, 329-336. https://bit.ly/2Nxj$3 \mathrm{CA}$

Cockerham, W. C. (1997): The Social Determinants of the Decline of Life Expectancy in Russia and Eastern Europe: A Lifestyle Explanation. Journal of Health and Social Behavior, 38, 2, 11, 7-30. DOI: 10.2307/2955420, https://bit.ly/2Qtu070

Elekes Zs. (2014): Hungary's Neglected Alcohol Problem? Alcohol Drinking in a Heavy Consumer Country. Substance Use \& Misuse, 49, 12, 1611-1618. DOI: 10.3109/10826084.2014.913396

Elekes Zs. - Liptay G. (1987): Az alkoholfogyasztás és más deviáns viselkedési formák elterjedése Magyarországon. In: Kolozsi B. - Münnich I. (szerk.): A társadalmi beilleszkedés zavarainak kutatása. (Tájékoztató Bulletin 11) Budapest: A társadalmi beilleszkedés zavarainak kutatása Programtanácsa

Józan P. (2003): Az alkohol hatása a halandóságra Magyarországon, 1970-1999. Budapest: Központi Statisztikai Hivatal Nemzeti Népesedési Program 
Kósa Zs. - Széles Gy. - Kardos L. et al. (2007): A Comparative Health Survey of the Inhabitants of Roma Settlements in Hungary. American Journal of Public Health, 97, 5, 853-859. DOI: 10.2105/ ajph.2005.072173, https://ajph.aphapublications.org/doi/full/10.2105/AJPH.2005.072173

Kovács K. (1991): Az alkoholkérdés megoldásainak a kísérletei Magyarországon - Az intézményrendszer fejlődésének főbb tendenciái (különös tekintettel az 1945 utáni korszakra). In: Münnich I. - Kolozsi B. (szerk.): Társadalmi Beilleszkedési Zavarok (Bulletin XX. A) 132-197. Budapest: Társadalmi beilleszkedési zavarok c. kutatás Programirodája.

Lapis K. (2002): Az alkoholos májcirrhosis és egyéb alkoholos eredetủ májbetegségek. Magyar Tudomány, XLVIII, 4, 472-488. http://epa.oszk.hu/00700/00775/00041/pdf/EPA00691_magyar_tudomany_2002-04_472-488.pdf

Mackenbach, J. P. - Kulhánová, I. - Bopp, M. et al. (2015): Inequalities in Alcohol-related Mortality in 17 European Countries: A Retrospective Analysis of Mortality Registers. PLOS Medicine, DOI:10.1371/journal.pmed.1001909, https://journals.plos.org/plosmedicine/article?id=10.1371/ journal.pmed.1001909

Meslé, F. (2004): Mortality in Central and Eastern Europe: Long-term Trends and Recent Upturns. Demographic Research Special Collection, 2, 3, 45-70. DOI: 10.4054/DemRes.2004.S2.3, https://www.demographic-research.org/special/2/3/s2-3.pdf

Nagy Cs. - Juhász A. - Papp Z. et al. (2013): Hierarchical Spatio-temporal Mapping of Premature Mortality Due to Alcoholic Liver Disease in Hungary. European Journal of Public Health, 24, 3, 827-833. DOI: 10.1093/eurpub/ckt169, https://academic.oup.com/eurpub/article/24/5/827/475685

Preston, S. - Heuveline, P. - Guillot, M. (2001): Demography Measuring and Modeling Population Processes. Willey-Blackwell

Ramstedt, M. (2007): Population Drinking and Liver Cirrhosis: Is There a Link in Eastern Europe? Addiction, 102, 8, 1212-1223. DOI: 10.1111/j.1360-0443.2005.01009.x

Szücs S. - Sárváry A. - Mckee, M. et al. (2005): Could the High Level of Cirrhosis in Central and Eastern Europe Be Due Partly to the Quality of Alcohol Consumed? An Exploratory Investigation. Addiction, 100, 536-542. 